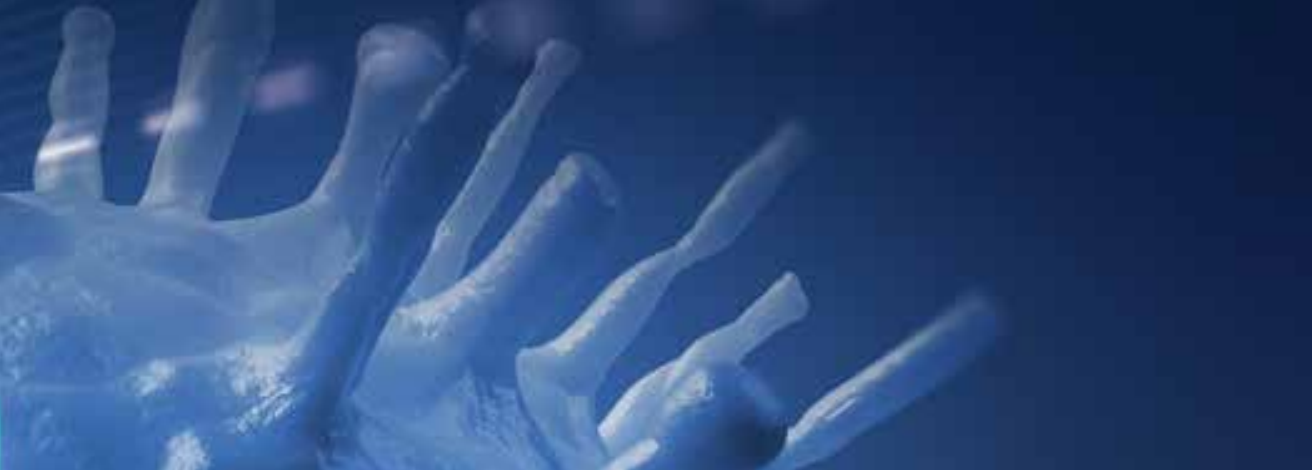

\title{
Violence against children and adolescents in the time of COVID-19'
}

ECLAC-UNICEF-Office of the Special Representative of the Secretary-General on Violence

- Neglect, physical, sexual and emotional abuse, and harmful practices, such as child marriage and early unions, are ways in which the integrity and rights of children and adolescents (any person under the age of 18) are violated (UNICEF, 2015). It has been noted for decades that no country is immune to violence against children, that the different forms of violence can occur in the home, in schools, care or justice institutions, the community or in the digital environment (Pinheiro, 2006) and that 50\% of the global population under 18 has been the victim of violence (WHO, 2020a), most of which tends to be perpetrated by family members or people close to them. Such violence affects children differently and may occur in contexts where additional risk factors give rise to other forms of violence. These include violations of the rights of children and adolescents in times of armed conflict (United Nations, 2013), trafficking in children and adolescents (UNODC, 2020) and child labour (ILO, 1999), all of which affects the physical, psychological and social integrity of children and adolescents and limits their possibilities for development.

- During the coronavirus disease (COVID-19) crisis, factors such as limitations on economic activity, school closures, reduced access to health-care services and physical distancing increase the likelihood of children and adolescents becoming vulnerable and being exposed to violence and other violations of their rights (Bhatia and others, 2020; UNICEF, 2020b). In Latin America and the Caribbean, the gradual deterioration in socioeconomic factors in the past decade (ECLAC, 2020a) has reduced essential elements of protection and may generate an even sharper increase in violence against children and adolescents in the time of COVID-19 than before the crisis (WHO, 2020a). Factors such as pre-existing inequalities in the region

\section{Contents}

I. What are the forms of violence in the home?

II. The imbalance between risk factors and protection factors in Latin America and the Caribbean.

III. Risks that are heightened by the COVID-19 crisis.

IV. Protection of children and adolescents as a priority in the new agenda .8

Bibliography 12

The cut-off date for the information used to prepare this report is 31 August 2020 
in terms of socioeconomic conditions, housing and access to health mean that some groups, such as migrant families, are at higher risk of contracting the virus and suffering from the impact of the crisis on the countries of the region (Tres and Chatruc, 2020).

- The imbalance between risk factors and protection factors (UNICEF, 2020a) will depend on the extent to which countries implement physical distancing measures to help contain the pandemic (WHO, 2020b). Socioeconomic inequality in the region means that compliance with health measures is not uniform (ECLAC, 2020b), which implies greater risk for children and adolescents, especially those who are most vulnerable ${ }^{2}$ to trafficking in persons or sexual exploitation (UNODC, 2020), child labour (ILO/ECLAC, 2020) or sexual offences, including those committed using digital media (INTERPOL, 2020; EUROPOL, 2020). In the context of the COVID-19 pandemic, many children and adolescents spend most of their time at home with their parents and caregivers (UNICEF, 2020b), and in the digital environment they are able to interact with people in other settings, such as school and the community (INTERPOL, 2020). However, it is within the home and family ${ }^{3}$ that violence is most often perpetrated against children and adolescents, and against adult women. While the impact of violence may vary when perpetrated against adults, both groups suffer similar consequences, such as effects on mental health and sexual and reproductive health, and also share risk factors, such as social norms that condone both types of violence and prevent help-seeking (Guedes and others, 2016). This is important to note, because violence witnessed by children or adolescents has physical and psychological impacts similar to those experienced by victims of direct violence (UNICEF, 2006).

- This document examines the exacerbation of risks and the erosion of protection factors relating to physical, psychological and sexual violence in the home experienced by adolescents and children, especially girls, within the context of COVID-19 in the region. It also provides recommendations on the integration of concrete actions into the response mechanisms developed by Latin American and Caribbean States to address the COVID-19 crisis.

\section{What are the forms of violence in the home?}

violence against children and adolescents is not random. It is deliberately perpetrated by a third person and thus, must and can be prevented. Children and adolescents may be exposed to conditions in the household that increase the possibility of violence perpetrated against them by their parents, caregivers, peers, siblings, or relatives and people close to them with whom they interact regularly or live (Alliance for the Protection of Children and Adolescents in Humanitarian Action, 2020). These factors must be identified and addressed in a timely manner to prevent violent situations arising. However, violence against children and adolescents in the home is not limited to that perpetrated by members of the household or people close to them. The increased use of digital tools as a result of the social isolation measures adopted in most countries in the context of the pandemic (Blackman and others, 2020) broadens the spectrum of potential perpetrators outside the family to include people they can interact with in the digital environment, such as peers or strangers (ITU, 2020; EUROPOL, 2020).

The Committee on the Rights of the Child defines physical and humiliating punishment as "any punishment in which physical force is used and intended to cause some degree of pain or discomfort, however light. (...) In addition, there are other non-physical forms of punishment that are also cruel and degrading and thus incompatible with the Convention [on the Rights of the Child]. These include, for example, punishment which belittles, humiliates, denigrates, scapegoats, threatens, scares or ridicules the child."

General Comment No. 8, Article 11

(United Nations, 2006)
Children and adolescents who are refugees, stateless, migrants, in detention, institutionalized, or who are already victims of violations such as child labour or find themselves in situations of conflict and vulnerability (UNICEF, 2020e).

This paper takes into account the wide diversity of households in the region, including single-parent households headed by women or men; traditional two-parent households; households including stepfathers or stepmothers; extended family households; or households headed by older persons, with no parents. 


\section{A. Physical and psychological violence expressed through physical and humiliating punishment and degrading treatment}

- Physical punishment is very common, even during the first five years of a child's life (UNICEF, 2020a) and is related to psychological violence as a parenting practice (United Nations, 2006). Recent estimates indicate prevalence of $55.2 \%$ of physical aggression and $48 \%$ of psychological aggression in child-rearing in Latin America and the Caribbean (Cuartas and others, 2019).

\section{B. Sexual violence}

- Sexual violence is considered a serious violation of the rights of children and adolescents and can take the form of abuse, harassment or sexual exploitation (UNICEF, n/db). It consists of sexual activity influenced by unequal power relationships. In the case of sexual exploitation, it involves remuneration or the promise of remuneration directly or to a third party (ECPAT International, 2020). With regard

Online sexual violence includes grooming, live streaming, the consumption of child sexual abuse material and coercion or extortion of children and adolescents for sexual purposes.

(ECPAT International, 2018) to sexual violence in the home, in most cases reported up until the pandemic, the perpetrators were family members or people close to the victims $(\mathrm{WHO}$, 2020a), and most of the victims were girls and adolescent girls.

\section{Violence in the digital environment}

- Information and communications technologies (ICTs) are one of the most important tools used during the COVID-19 crisis. Despite the gaps in coverage and penetration of the Internet in the countries of the region, the digital world is the best bridge to ensure the continuity of daily activities, such as school, work and communication (Trucco and Palma, 2020). However, increased exposure to the digital environment may in turn increase vulnerability to risks inherent in ICTs, such as cyberbullying or sexual violence through digital media, of which children and adolescents may be victims (EUROPOL, 2020). Cyberbullying is repeated intimidation ${ }^{4}$ through social networks, messaging platforms, virtual communities, gaming platforms or mobile phones, aimed at frightening, angering or shaming others (UNICEF, n/da). It is related to systematic intimidation in non-digital environments, and the increase in the number of hours that children and adolescents spend on the Internet significantly increases the risk of it happening (ITU, 2020).

- Online violence is not a separate problem from violence in the offline world (WHO, 2020a) and, in the case of online sexual violence, children and adolescents who do not even have access to an electronic device may also be affected. Today it is common for adults to have access to digital cameras, laptops or cell phones that allow them to record sexual activity with children and adolescents, as well as the distribution of this material through digital channels from their own homes (ECPAT International, 2020).

\section{Link between violence against women and violence against children and adolescents}

- Violence against women and violence against children and adolescents reflect similar risk factors and social norms that lead to the perpetration and tolerance of these phenomena. These social norms often discourage help-seeking and underlie episodes of violence within the home or family (Guedes and others, 2016). They stem from patriarchal ideas of gender roles, which also have a negative impact on parenting roles and practices. The exposure of children and adolescents to violence perpetrated against other people has physical and psychological effects similar to those caused by violence experienced directly (UNICEF, 2006; ECLAC/UNICEF, 2018). In addition, systematic violence against other members of the household is itself a significant risk factor of violence towards this age group.

- A recent comprehensive review of research on violence against women and violence against children and adolescents in Latin America and the Caribbean (Bott and Ruiz-Celis, 2019) confirmed

\footnotetext{
4 Through defamation or dissemination of audiovisual material embarrassing to the victim, hurtful or threatening messages, or impersonation (UNICEF, n/da).
} 
the findings of the Pan American Health Organization in 2016 (Guedes and others, 2016) on the intersections between violence perpetrated against women and violence against children and adolescents. The study found that these intersections are manifested in the region in aspects such as social norms that promote and justify physical violence as a form of discipline in parenting and in intimate partner relationships. In 2019, as many as $36 \%$ of women in the region thought that physical punishment was necessary in child-rearing and up to $16.6 \%$ believed that wife-beating was justified (Bott and Ruiz-Celis, 2019).

\section{E. The effects of violence}

- For decades, warnings have been issued about violence against children and adolescents, which is a universal problem, and its short-, medium- and long-term physical and psychosocial effects on victims and society (Pinheiro, 2006). The exposure to violence, particularly in the first years of life, affect brain structure and result in lifelong impairments in cognitive and emotional capacities, in addition to contributing to high-risk and antisocial behaviour (Cuartas, 2019). This means that the several aspects of the lives of children and adolescents who are victims of violence may be affected: poorer school performance, reduced ability to interact with others and to establish healthy emotional bonds, greater predisposition to irresponsible sexual behaviour or abuse of psychoactive substances, and a predisposition to chronic mental health disorders (Cuartas, 2019).

\section{The imbalance between risk factors and protection factors} in Latin America and the Caribbean

- While violence occurs across all socioeconomic groups, poor socioeconomic conditions are associated with greater exposure to risks and limited protection factors. Protective elements that do not depend fully on the individual, such as adequate access to technology and information, economic security and stability, education and knowledge about children, care and child-rearing are scarcer among the poor, who in turn are more exposed to violent people and environments, abuse of psychoactive substances and normalization of violent behaviour (UNICEF, 2020a). Moreover, when the COVID-19 crisis spread to Latin American and the Caribbean, the region was already in the midst of a migration crisis, owing mainly to the mass departure of migrants from the Bolivarian Republic of Venezuela to other countries in the region, and from Central America to North America (Tres and Chatruc, 2020), which has resulted in limited access to housing, basic water and sanitation services, and health care, for example. The migrant population faces difficulties in accessing basic rights and services, which exposes them to more risks and means that they have even less access to already limited protection factors (United Nations, 2020b). The COVID-19 crisis is also having a significant impact on women, because of their burden of care work and because they are overrepresented in the economic activities most affected by preventive social isolation measures. Indigenous peoples and Afrodescendants are also expected to be more affected by the crisis, since they tend to live in worse socioeconomic conditions and have more limited access to public services than the rest of the population, in addition to facing historical discrimination (ECLAC/PAHO, 2020).

- The coronavirus disease (COVID-19) officially arrived in the region on 26 February, when the first case was reported in Brazil, and since then Latin American and Caribbean countries have gradually taken measures similar to those seen in other parts of the world, such as limiting all transport to strictly essential operations to tackle the pandemic, suspending in-person attendance in schools and offices, confining people to their homes and encouraging physical distancing (WHO, 2020b). In August 2020, measures such as border closures and the suspension of international trade, mandatory isolation and the suspension of activities in multiple economic sectors remained in place in most countries in the region (OECD, 2020). This has prolonged the negative impact on the security and stability of family income (ECLAC/ILO, 2020) and on the mental health of parents and caregivers (Anderson and others, 2020). 


\section{A. The socioeconomic effects of the crisis exacerbate risks}

- When the pandemic and its consequences spread to Latin America and the Caribbean, the region was inadequately prepared for a challenge that only materialized at the end of the first quarter of the year, despite the fact that it had had more time to prepare than countries in the

Children are not the face of this pandemic. But they risk being among its biggest victims.

UNICEF (2020b, p.2) northern hemisphere. In record time, governments were forced to marshal an unprecedented amount of resources to strengthen the health sector and to provide social protection for large swathes of the population (ECLAC, 2020c). With a view to containing the spread of infection and avoiding the saturation of health systems, Latin American and Caribbean governments had to enforce strict physical distancing measures that resulted in a decrease in domestic economic activity. In addition to the domestic disruptions, international trade has declined, commodity prices have fallen, global value chains have been interrupted, demand in the travel and tourism sector has weakened and global financial conditions have deteriorated (ECLAC, 2020a).

- The COVID-19 crisis is expected to increase poverty. Along with family income insecurity, restrictions on free movement, isolation and overcrowding considerably increase stress and anxiety for parents and caregivers, as well as for children and adolescents (WHO, 2020a). While isolation measures have been an adequate response to an unprecedented pandemic as they have helped to contain the spread of the virus in most countries, the capacities of developed nations and of developing countries (such as those in Latin America and the Caribbean) to recover from the social and economic effects of these measures vary dramatically (Cornia, Jolly and Stewart, 2020). This is because developing countries are more likely to lack social protection systems that can guarantee people's well-being while economic activity is suspended. This contrasts with greater development and capacity in infrastructure, technology and skills (among other factors) in developed countries, which have not only enabled them to tackle the crisis more quickly with fewer resources (or greater investment capacity), but will also facilitate the public investment needed to intervene in the areas affected by the pandemic (ECLAC, 2020b).

- ECLAC (2020d) projects that the number of people living in poverty in Latin America will grow by 45.4 million in 2020, pushing the total number of people living in poverty up from 185.5 million in 2019 to 230.9 million in 2020, representing 37.3\% of the Latin American population. Within this group, the number of people living in extreme poverty is expected to increase by 28.5 million, from 67.7 million in 2019 to 96.2 million in 2020, equivalent to $15.5 \%$ of the total population.

- In Latin America and the Caribbean, the deepest recession in decades - a 9.1\% decline in GDP is projected (ECLAC, 2020d) - is expected to be reflected in the contraction of most markets, which will occur in a large number of emerging countries (World Bank, 2020). The number of children living in monetary poverty in Latin America is projected to rise by up to 7.6 percentage points, meaning that $51.3 \%$ of that population group will be affected (or one in every two children and adolescents) (ECLAC/UNICEF, 2020). This is expected to coincide with the worsening of the education crisis, increased threats to health, development and survival, and exposure to the risk of violence and other violations (UNICEF, 2020b).

- People living in households in acute multidimensional poverty face severe deprivations in areas fundamental to survival (adequate food, access to public services, schooling or adequate housing) that mainly affect children and adolescents (Alkire and others, 2020; Santos, 2020). Although some types of cohabitation between households can be practical or even favourable for the collective well-

"What began as a health crisis risks evolving into a broader child-rights crisis."

António Guterres, Secretary-General of the United Nations Message of the Secretary-General of the United Nations on the impact of the COVID-19 pandemic on children being, the presence of too many people in the housing complex may lead to problems of coexistence, violence in the home and a lack of privacy (UN Habitat, 2015), which present a risk of sexual violence.

- The precariousness of the socioeconomic conditions faced by families is compounded by the fact that educational institutions in Latin America and the Caribbean, like those of more than 190 countries around the world, suspended in-person classes and kept students of all education levels out of schools (UNESCO, 2020; ECLAC/UNESCO, 2020). Although this measure has allowed 
the physical distancing required to contain the spread of infection (WHO, 2020b), it has resulted in a large number of children and adolescents in education being confined to their homes, leaving unprotected the millions who depend on school and associated social programmes to meet other needs such as food or early childhood care (UNICEF, 2020b). This measure drastically limited the possibilities for teachers to detect and report cases of violence, to provide support and guidance, and to activate response measures (Peterman, O'Donnell, Palermo, 2020). Moreover, in most countries (OECD, 2020) in-person health services prioritized cases related to COVID-19, which limited health workers' ability to detect possible cases of violence.

\section{B. More time on the Internet without adequate guidance and supervision means more risk}

- The digital environment has allowed those who have access to it to continue education and work activities, to access and interact with public services, and to communicate with family and friends, among other things. Much of community life, access to public services and procedures, social interaction, remote work and study and entertainment moved to digital environments (UNICEF, 2020b). However, it is estimated that only 4 out of 10 households in Latin America and the Caribbean have access to broadband Internet, while less than $50 \%$ have access to mobile Internet (CAF, 2020). This limited access has a negative impact on interventions that, prior to the pandemic, were carried out through home visits and in child development centres, and have now been replaced by remote support. In addition, the lack of digital literacy and the knowledge gap between adults and children and adolescents (CAF, 2020) may limit parents' and caregivers' ability to provide support in distance learning tasks and, in the case of children under five years of age, nurturing care work carried out in day-care centres or childcare centres (WHO, 2018).

- Children and adolescents in quarantined families spend a considerable amount of time in digital environments to study, socialize and play (End Violence Against Children, 2020a). This online time increases their exposure to potential abusers on the Internet (End Violence Against Children, 2020b), because of the large number of digital spaces where they spend their free time during isolation, in which include virtual games and communities that allow them to interact freely with other unknown players (Centre for Sport and Human Rights, 2020), who may be potential perpetrators using these tools to groom victims (INTERPOL, 2020; EUROPOL, 2020).

\section{Why is the real magnitude of the problem not yet known?}

- By the end of August 2020, it was still too early to tell exactly how much and in what ways violence against women and violence against children and adolescents in the household and other settings have changed during the COVID-19 crisis. Challenges in measuring the different forms of violence already existed before the start of the pandemic, not only because of the difficulty of detecting cases (partly because of the normalization of violence, which means that victims, perpetrators and witnesses do not see it as a problem), but also because many countries have yet to build or improve information systems (WHO, 2020a). Most of the information available comes from administrative records that do not allow for the measurement of prevalence, particularly when dealing with data from a limited number of sources and only for some months (Peterman, O'Donnell and Palermo, 2020). The true picture of violence during isolation in the region is not expected to be clear until several months after restrictions on movement have been lifted, but various sources and sectors expect that it will show an increase in the magnitude and severity of violence compared to the period before the pandemic (WHO, 2020a).

- The rise in instances of violence is mainly reflected in the higher number of administrative records of cases reported through reporting and assistance platforms, mostly relating to intimate partner violence, especially against women (Peterman and others, 2020b). In practice, this increase in records may be explained by reasons other than an actual rise in cases, such as the effectiveness of communication strategies during the crisis to promote the use of specific reporting mechanisms. For this reason, sources such as administrative records are imprecise when trying to determine the magnitude of the problem. They are limited to the monthly count of known cases - and not necessarily the response elicited - and do not take into account factors such as seasonal fluctuations and underreporting of cases that could not be detected in schools or health centres (Baron, Goldstein and Wallace, 2020). However, detection may 
decrease compared to the months prior to a crisis such as that of COVID-19, as has been the case in the wake of other emergencies around the world (Seddighi and others, 2019). In countries such as the United States, it is estimated that reports of violence against children decrease by more than 60\% when they do not attend school (Fitzpatrick, Benson and Bondurant, 2020), and a similar trend is seen when women are not in the workplace or having regular contact with their extended family or community, meaning that cases of violence go undetected (Peterman, O'Donnell and Palermo, 2020a). In other words, the figures do not necessarily reveal a decrease or increase in cases, but rather a decline in detection capacity.

\section{Risks that are heightened by the COVID-19 crisis}

- It must be stressed that neither COVID-19 nor the measures to contain it cause the violence that is perpetrated against children and adolescents. Nonetheless, the ongoing crisis has heightened risk factors and eroded protection factors. As a result, under current conditions, children and adolescents in the region are more exposed than ever to severe physical or psychological violence (such as the use of physical or humiliating punishment as a parenting practice), neglect, sexual violence and online violence.

- The combination of these factors in turn creates conditions for the number of cases of physical, sexual and psychological violence to increase even more (Cornia, Jolly and Stewart, 2020). Heightened stressors, such as socioeconomic factors and those related to family life in isolation, have psychological consequences that can put a strain on adults and compromise their ability to respond to children's and adolescents' needs, leading them to respond aggressively (Center on the Developing Child, Harvard University, 2016 cited in Cuartas, 2020). Moreover, a review of empirical evidence from previous pandemics and emergencies suggests that women and girls are at greater risk of systematic sexual assault during isolation (Peterman and others, 2020b; Seddighi and others, 2019; Bandiera and others, 2018; Anderberg and others, 2016).

- In the context of this crisis, there are two major amplifiers of the risk of sexual violence: on one hand the above-mentioned closure of places where cases would normally be detected, such as schools and health centres, or reductions in their face-to-face services, and on the other hand increases in the hours that children and adolescents and perpetrators spend online (INTERPOL, 2020; EUROPOL, 2020). In many cases, children and adolescents even share a home with potential abusers and confinement means they spend more time together. In other words, there is a larger window of exposure to greater risk and less capacity to detect cases and support victims (ITU, 2020). Furthermore, abusers are exploiting the increase in vulnerability factors and higher number of children and adolescents at risk, by adapting to grooming victims online and in non-digital settings (UNODC, 2020). Police forces and specialized agencies around the world agree that they have detected increases in sexual crimes against children and adolescents during the COVID-19 pandemic; as it is more difficult to gain access to their victims in their usual way, most abusers are exploiting the possibilities of digital tools (ECPAT International, 2020; INTERPOL, 2020).

- In the times of COVID-19 it is easier than ever for sex offenders to access, download, produce and share material of sexual abuse of children and adolescents (ECPAT International, 2020). For this, they use open networks, the deep web, the darknet and peer-to-peer networks (EUROPOL, 2020). As a result, criminal police

“We've had tips of web pages where perpetrators are discussing how the situation we are in now can be exploited".

Anna Karin Hildingson Boqvist (ECPAT International, 2020) authorities have detected an increase in activity related to sexual violence against children and adolescents. This has been clearly reflected by a rise in attempts to access websites that have been blocked because they were hosting this type of content, as well as in increased exchanges of audiovisual material in online communities of offenders and more discussions on forums regarding opportunities for sexual exploitation and abuse in the current circumstances (EUROPOL, 2020). 


\section{Protection of children and adolescents as a priority}

in the new agenda

- The gradual resumption of activities has focused attention on the near term. During the preparation of this document it became apparent that there is a shortage of information on the outlook for the region and the world in the short and long term, and that too many elements needed to make accurate forecasts are still missing. This fuels despair, stress and widespread anxiety among adults, but also among children and adolescents, whose needs should be even more of a priority, yet they have often been given the least consideration. Evidently, countries must engage in dialogue about the post-pandemic world; the current situation is an ideal opportunity for dialogue with children and adolescents about what they want and what they do not want in the world they will inherit. This will not only provide insight into their views and allow for them to be taken into account during the reconstruction process, it will also help to create shared goals for society and reduce the anxiety caused by uncertainty about the future.

- Some governments have implemented specific actions to address violence against children and adolescents, such as expanding helplines, launching awareness-raising campaigns, funding shelters for survivors, improving access to services for survivors, and amending family law and justice systems (Guedes, Peterman and Deligiorgis, 2020). These measures must be implemented systematically and strengthened if they are to reduce violence against children during and after the COVID-19 crisis.

v In this regard, following the call from the Secretary-General of the United Nations to redouble efforts to protect children during the pandemic, the main agencies of the United Nations system that are responsible for this area have put together an Agenda for Action to protect children and adolescents from violence, which outlines three major areas of work to prevent violence during and after the crisis: more information (production of reliable data and appropriate dissemination); more solidarity for the protection of the most vulnerable; and more child-rights and multisectoral action (Inter-Agency Working Group on Violence against Children, 2020).

- The Agenda for Action must be translated as soon as possible into specific actions in the countries of Latin America and the Caribbean. The response to the pandemic has clearly required an unprecedented fiscal effort in the countries of the region and the world in general. Therefore, actions to address violence in the context of the crisis must form part of existing public investment or of initiatives that require a minimal fiscal effort.

- It is recommended that the following actions be taken, to address violence against children and adolescents within the framework of the response to the COVID-19 crisis. They are adapted to the fiscal possibilities of the countries of the region, and their scope covers not only isolation, but also the gradual return to activity. Most of the recommendations allow for actions to be adapted to existing resources or to address different areas at the same time:

A. Addressing violence against children and adolescents as a priority in States" crisis agendas and its inclusion in the agendas of the high-level intersectoral bodies created to respond to the COVID-19 crisis

- High-level inter-institutional coordination bodies have been set up in different countries, chaired by heads of State and their cabinets, which have proved effective in making all the resources of governments and of their allies available to resolve the COVID-19 crisis. This has allowed resources to be allocated to areas ranging from improving health infrastructure against the clock, to providing financial assistance to people and sectors affected by the socioeconomic repercussions of the crisis.

- The 2030 Agenda for Sustainable Development urges States to prevent and eliminate violence against children and adolescents (target 16.2 of the Sustainable Development Goals), a key issue for the sustainability of countries. This commitment is even more significant in the context of the COVID-19 crisis, regardless of whether or not there were public commitments or specific plans to address such violence prior to the pandemic. Given the seriousness of the problem and its implications, it must be discussed — with leadership from heads of State and their cabinets- within the aforementioned high-level inter-institutional coordination bodies, which 
would be able to coordinate plans that draw on technical, financial and human resources from all stakeholders and not just the entities responsible for protecting children and adolescents.

- Similarly, it is important to ensure that the services available to survivors of violence are kept open, and that the people working for such services are categorized as essential staff, with access to the necessary biosafety equipment and training to deal with cases according to gender and age.

\section{B. Resource optimization through the alignment of services offered}

- One of the success factors in the response of the region's countries to the crisis has been the alignment of services offered. The INSPIRE ${ }^{5}$ strategic framework for the elimination of violence against children and adolescents was designed based on successful experiences, and demonstrates that elimination of violence is possible if a coordinated intersectoral approach is adopted. However, in order to respond to the COVID-19 crisis, countries have been forced to take immediate action, which has not always been within the framework of existing policies and strategies.

- Through the aforementioned coordination bodies, different ministries and government institutions have made budgets and programmes available for a joint response. The expertise and experience of public and private institutions are thus pooled in joint initiatives, optimizing resources in times of fiscal austerity and addressing several areas with comprehensive actions. Such actions may include:

1. Alignment of the response to violence against women, and against children and adolescents

- The response to the crisis has included the creation or bolstering of services to address violence in the home against women, such as hotlines for support and for reporting abuse, although these services require further strengthening. As explained in previous sections, it has been demonstrated that it is beneficial to take complementary actions to prevent violence against women, and against children and adolescents; they share risk factors and measures to counteract one form of violence directly impact the other. That is why it is important to create spaces for coordination, which allow technical, financial and infrastructure resources to be shared, while taking advantage of the expertise of the persons working on each of the topics. Possible measures include providing survivors with access to ad hoc reporting points, as has been done for women who are survivors of violence (for example, by setting up support points in markets or providing training to pharmacists), establishing specific applications and helplines for children and adolescents, or setting up emergency shelters for women who are survivors of violence in the home, where their children can also be accommodated.

2. Expanding the number of recipients of public assistance services during the COVID-19 pandemic
Safe accomodation in hotels for women and children victims of violence in Mexico

In response to the increase in intrafamily violence seen against the backdrop of the COVID-19 pandemic, UNICEF, the United Nations Population Fund (UNFPA), the Government of Mexico and the hotel sector have initiated the first phase of a strategy to provide safe and free accommodation in hotels for women and their children who are victims of violence while their cases are examined and different support networks or shelters are identified.

Even before the physical distancing measures imposed as a result of the pandemic, the home was already a dangerous place for women and their children. For example, according to surveys, $44 \%$ of women had experienced some form of violence at the hands of their current or last partner. Likewise, 6 out of 10 children aged between 1 and 14 years had been subject to some violent disciplinary measures in their homes, according to data from the 2015 National Survey of Children and Women (ENIM).

Moreover, between January and June 2020, emergency calls for incidents related to violence against women increased by $45.8 \%$ compared to the same period in 2019. Previous studies show that violence against women in the home also affects children and adolescents, just as a result of witnessing it and because, in most cases, the aggressor also behaves violently towards them.

- Although it may have initially involved additional public investment, most countries in the region have implemented programmes such as strengthening cash transfers and providing food baskets to large sections of the population. The return on this investment and on complementary interventions will be seen in the medium-term prevention of situations with high social costs,

\footnotetext{
5 For more information see [online] https://www.end-violence.org/inspire.
} 
which would require greater investment to resolve after the event. Similarly, it is important to reduce barriers to access to services and to eliminate the conditions that families, and specifically women, must meet to receive assistance.

3. Specific and differentiated programmes for children and adolescents who were already vulnerable

- Even before the COVID-19 crisis, vulnerable children and adolescents were a population group about which there was not always enough information to include them in standard State services. While it is important to formulate differentiated strategies that address this group's specific needs, including them in standard coverage will help to channel other assistance that mitigates the risks inherent in their vulnerability. Specific and differentiated interventions reduce the additional vulnerabilities faced by population groups that may be off the radar of States' social coverage: refugee, stateless, migrant, displaced, institutionalized, indigenous or Afrodescendent children and adolescents, those who are in street situations or who have been deprived of their freedom, as well as those who are already victims of violations such as child labour or find themselves in situation of conflict and fragility (UNICEF, 2020e).

\section{Promoting the care economy and balanced distribution of roles and tasks}

- The move from face-to-face to online classes and the new remote format of social programmes has meant that children and adolescents depend more than ever on their parents or caregivers to provide them with the care they need for their development and to complete their schoolwork, as well as to allow them to participate in leisure activities and other public programmes in which they were already enrolled. This has had an unexpected

The COVID-19 pandemic is exacerbating the care crisis in Latin America and the Caribbean (ECLAC, 2020e) For more information on how gender inequalities within households have increased during the pandemic see: [online] https://repositorio.cepal.org/bitstream/ handle/11362/45352/S2000260_en.pdf. benefit: in many cases it has increased the involvement of all members of households in the activities of children and adolescents, but it also creates an additional burden in terms of time and effort. In the case of vulnerable families, monetary or in-kind incentives could be offered (such as supplementary food subsidies or exemptions from payment for services) in recognition of time spent and to foster an active role for family members. However, since there is still progress to be made in fostering the equitable distribution of roles and tasks, such actions should also promote the active involvement of fathers and other men in the family unit.

\section{Transforming practices}

- The unprecedented efforts to address the COVID-19 pandemic have included effective communication strategies to rapidly transform people's habits, which have achieved this goal in the space of just a few months. Thanks to campaigns and strategies that have drawn on all media formats, people have learned self-care habits that were not part of everyday life months ago, such as more frequent hand washing, the use of masks and facemasks, and even the way people greet each other and show affection outside their close family units. These strategies will be maintained and strengthened over time, even more so as countries gradually return to activity.

- To reduce violence against children and adolescents in the home, it is important to incorporate knowledge, attitudes and practices that many families are not familiar with. The aforementioned initiatives can serve as a basis, for example, for proposing scenarios for communication within families, non-violent child-rearing practices, positive parenting, or suggesting household activities that incorporate gender equality into parenting.

6. Promoting an active role for teachers and other staff in early childhood development centres

- The suspension of face-to-face classes in educational institutions and early childhood development centres has also resulted in the elimination of one of the main sources of detection of violence against children and adolescents. At the same time, educators have had to adapt their interactions with their pupils to distance learning. In this respect, the reshaping of educational environments and teaching methods must include the strengthening of social and emotional skills, as well as 
specific content in classes regarding violence against children and adolescents and its structural causes (such as the social norms that perpetuate violence). Direct channels of communication among teachers, families and students must be strengthened, so that the relationship of trust enables children and adolescents to report situations of direct or indirect risk or violence to which they have been exposed. Support for the work of teachers should include training on talking to students about violence, as well as a redesign of processes for detecting cases and responding to identified cases. Where institutions have psychopedagogical staff, their active participation will be key both in formulating processes and protocols and in the care and referral of suspected cases.

\section{The prevention side of psychosocial support}

- Mental health care has been seen as one of the actions needed to respond to detected cases of violence. However, it is important for psychosocial care to be open to all, and not dependent on having been a victim of violence, for both children and women. This means that psychosocial care services must be made available to the general public, to prevent and treat mental health disorders such as depression, anxiety, suicidal thoughts, and stress in parents, caregivers, children and adolescents. These programmes should also promote assertive parenting and communication practices in the household. Although several countries have created portals and other information channels on such practices, mental health care on a case-by-case basis is important, accompanied by publicly available activities and complementary information. When providing these services, it is important to establish alternative channels, such as telephone or online support, that safeguards privacy and confidentiality.

In the Dominican Republic, the United Nations Children's Fund (UNICEF), the College of Psychologists of the Dominican Republic and the Institute of Mental Health and Telepsychology created an emotional support line for families called "Contigo".

The helpline is available 24 hours a day, 7 days a week, and offers free-of-charge remote psychological first aid, emotional support, psychoeducation and referral to services specialized in areas such as violence against children and adolescents, violence in the home, gender-based violence, suicide risk and psychiatric risk.

These services are available in Spanish, Haitian Creole and sign language, through phone calls, WhatsApp calls and chats, and a chat system on the website [online] www.lineafamiliar.do.

\section{Increasing the population's real access to information and telecommunications technology}

- Information and communications technologies (ICTs), especially online settings, have been important both for the public administration and for social relations during the COVID-19 crisis. While ICTs have enabled governments to reach their beneficiaries, the circumstances have also amplified the effects of the digital divide. Hence, it is important to:

- Make use of traditional media such as open radio and community stations to reach people in places with limited connectivity. This means adopting specific strategies for these media, not limited to information campaigns with standard messages.

- Establish partnerships with the private technology and telecommunications sector to expand Internet coverage to unserved areas, and to distribute electronic devices to families.

- Establish digital skills training programmes for parents and caregivers, allowing them to acquire knowledge and skills to learn about this environment, which is the one in which children and adolescents spend the most hours in many homes.

- Encourage a more active role for parents and caregivers through strategies to prevent violence in the digital environment. While strategies to promote self-care by children and adolescents are important and should be maintained and strengthened, it is important to encourage parents and caregivers to take on more active roles. In this way, the family itself can inform children and adolescents of the risks to which they are exposed through inappropriate Internet use. This requires proper ongoing training in digital environments.

- Promote the creation of tools such as applications that facilitate parental control of devices that children and adolescents use to interact in the digital environment. This reduces the possibility of contact with potential abusers or access to content that is not age-appropriate.

- Pursue strategies to regulate content and platforms, with a view to protecting the rights of children and adolescents, with the active involvement of the private sector. 


\section{E. High-impact actions in the working environment, at no added cost to employers}

- The risks related to the COVID-19 pandemic are forcing a rethink of dynamics in workplaces. This is an opportunity to make changes to eradicate some of the structural causes of violence against children, adolescents and women. In this regard, ECLAC has drawn attention to how gendersensitive policies can reduce gender inequalities in the household and in working environments, as well as evening out the distribution of care roles in the household (ECLAC, 2020e). This requires greater autonomy for women in the

The private sector can contribute significantly to preventing violence in the home and other settings. For more information on how businesses can be actively involved see: [online] https://violenceagainstchildren.un.org/ sites/violenceagainstchildren.un.org/ files/the_private_sector_and_the_ prevention_of_violence_against_ children_in_lac_-_ingl.pdf workplace, which will help to reduce effects that can lead to violence in the home, such as imbalanced power relations (Vaca Trigo, 2019). Within the framework of what it calls family-friendly policies, UNICEF has proposed a series of measures to design workplaces that increase the efficiency of staff and balance the well-being of families (UNICEF, 2019). The measures are aimed at encouraging men's involvement in the upbringing of their children, at creating spaces for pregnant and nursing mothers and at reducing stress levels for mothers and fathers. Family-friendly policies can ensure a proper balance between the work and family life of adults. These policies include paid parental leave, medical leave for the care of ill children, provision of workplace childcare, flexible working hours and benefits for each child.

\section{F. Creating solutions and opportunities at the local and community levels, with the genuine participation of children and adolescents}

- Although the conditions of isolation and the gradual return to activity limit face-to-face interactions of children and adolescents with community members and with relatives with whom they do not live, as described above, these conditions create an additional risk of violence. Local and community authorities can use available resources to establish mechanisms that enable online interaction or respect minimum physical distancing, allowing people's daily lives to expand beyond the privacy of their homes. This can be done by promoting free community videoconference platforms and telecommunications services among family members (such as mobile phone calls). Similarly, local authorities, traditional authorities of indigenous peoples and leaders of faith-based communities can play an important role, as through them beneficiaries of programmes can be reached more effectively.

\section{Bibliography}

Alkire, S. and others (2020), "Multidimensional poverty and COVID-19 risk factors: a rapid overview of interlinked deprivations across 5.7 Billion People", OPHI Briefing, vol. 53, Oxford Poverty and Human Development Initiative, Universidad de Oxford.

Alliance for Child Protection in Humanitarian Action (2020a), Technical Note: Protection of Children during the Coronavirus Pandemic (v. 1), May.

_(2020b), COVID-19 and its Implications for Protecting Children Online, Geneva, April.

Anderberg, D. and others (2016), “Unemployment and domestic violence: theory and evidence", The Economic Journal, 1947-1979.

Anderson, R. M. and others (2020), "How will country-based mitigation measures influence the course of the COVID-19 epidemic?", The Lancet, vol. 395.

Bandiera, O. and others (2018), "The economic lives of young women in the time of Ebola: lessons from an Empowerment Program", World Bank Policy Research Working Paper, No. 8760.

Baron, E., E. Goldstein and C. Wallace (2020), Suffering in Silence: How COVID-19 School Closures Inhibit the Reporting of Child Maltreatment, 14 May [online] https://ssrn.com/abstract=3601399 or http:// dx.doi.org/10.2139/ssrn.3601399.

Bhatia, A. and others (2020), Comment: Beyond children as "invisible carriers": The implications of COVID-19 response measures on violence against children [online] https://www.who.int/bulletin/volumes/ 98/9/20-263467/en/.

Blackman, A. and others (2020), Public Policy to Tackle Covid-19: Recommendations for Latin America and the Caribbean, Washington, D.C., Inter-American Development Bank (IDB). 
Bott, S. and A. Ruiz-Celis (2019), "Intersecciones entre violencia contra las niñas y niños y violencia contra las mujeres en América Latina y el Caribe", unpublished.

CAF (Development Bank of Latin America) (2020), El estado de la digitalización de América Latina frente a la pandemia del COVID-19. Observatorio CAF del Ecosistema Digital, April [online] https://scioteca.caf. com/bitstream/handle/123456789/1540/El_estado_de_la_digitalizacion_de_America_Latina_frente_a_ la_pandemia_del_COVID-19.pdf?sequence=1\&isAllowed=y.

Centre for Sport and Human Rights (2020), An Overview of the Sport-Related Impacts of the COVID-19 Pandemic on Children, Geneva.

Cornia, G. A., R. Jolly and F. Stewart (2020), "COVID-19 and children, in the North and in the South", Innocenti Discussion Papers, April, 1-10 [online] https://www.unicef-irc.org/publications/1087-covid-19and-children-in-the-north-and-the-south.html.

Cuartas, J. (2020), "Heightened risk of child maltreatment amid the COVID-19 pandemic can exacerbate mental health problems for the next generation," Psychological Trauma: Theory, Research, Practice, and Policy [online] https://doi.org/10.1037/tra0000597.

(2019), “Violencia contra niñas, niños y adolescentes: etiología, consecuencias y estrategias para su prevención", Report for the Colombian Institute of Family Welfare, unpublished.

Cuartas, J. and others (2019), "Early childhood exposure to non-violent discipline and physical and psychological aggression in low- and middle-income countries: national, regional, and global prevalence estimates", Child Abuse \& Neglect, vol. 92.

ECLAC (Economic Commission for Latin America and the Caribbean) (2020a), "Latin America and the Caribbean and the COVID-19 pandemic: economic and social effects", Special Report COVID-19, No. 1, Santiago, 3 April.

(2020b), "The social challenge in times of COVID-19", Special Report COVID-19, No. 3, Santiago, 12 May. (2020c), "Measuring the impact of COVID-19 with a view to reactivation", Special Report COVID-19, No. 2, Santiago, 21 April.

(2020d), "Addressing the growing impact of COVID-19 with a view to reactivation with equality: New projections", Special Report COVID-19, No. 5, Santiago, 15 July.

(2020e), The COVID-19 pandemic is exacerbating the care crisis in Latin America and the Caribbean, Santiago, April 2020.

ECLAC/FAO (Economic Commission for Latin America and the Caribbean/Food and Agriculture Organization of the United Nations) (2020), "Preventing the COVID-19 crisis from becoming a food crisis: Urgent measures against hunger in Latin America and the Caribbean", COVID-19 Report. ECLAC-FAO, Santiago.

ECLAC/ILO (Economic Commission for Latin America and the Caribbean/International Labour Organization) (2020), "Work in times of pandemic: the challenges of the coronavirus disease (COVID-19)", Employment Situation in Latin America and the Caribbean, No. 22 (LC/TS.2020/46), Santiago.

ECLAC/PAHO (Economic Commission for Latin America and the Caribbean/Pan-American Health Organization) (2020), "Health and the economy: A convergence needed to address COVID-19 and retake the path of sustainable development in Latin America and the Caribbean", COVID-19 Report ECLAC-PAHO, Santiago, 30 July.

ECLAC/UNESCO (Economic Commission for Latin America and the Caribbean/United Nations Educational, Scientific and Cultural Organization) (2020), "Education in the time of COVID-19", COVID-19 Report ECLAC-UNESCO, Santiago, August.

ECLAC/UNICEF (Economic Commission for Latin America and the Caribbean/United Nations Children's Fund) (2020), "Protección social para familias con niños, niñas y adolescentes en América Latina y el Caribe: un imperativo frente a los impactos del COVID-19. Informes COVID-19", unpublished.

(2018), Latin America and the Caribbean 30 years after the adoption of the Convention on the Rights of the Child (LC/PUB.2018/21), Santiago.

ECPAT International (2020), Why Children are at Risk of Sexual Abuse and Exploitation during COVID-19 [online] https://www.ecpat.org/news/covid-19-sexual-abuse/.

(2018), Online Child Sexual Abuse Material-The Facts [online] https://www.ecpat.org/news/online-childsexual-abuse-material-the-facts/.

End Violence Against Children (2020a), "Stay Safe at Home. Stay Safe Online" [online] https://www.endviolence.org/safeonlinecovid.

(2020b), COVID-19 and its Implications for Protecting Children Online, Geneva, April.

EUROPOL (2020), Exploiting isolation: Offenders and victims of online child sexual abuse during the COVID-19 pandemic, 19 June [online] https://www.europol.europa.eu/publications-documents/ exploiting-isolation-offenders-and-victims-of-online-child-sexual-abuse-during-covid-19-pandemic.

Fitzpatrick, M., C. Benson and S. Bondurant (2020), "Beyond reading, writing and arithmetic: the role of teachers and schools in reporting child maltreatment", NBER Working paper Series, No. 27033. 
Guedes, A., A. Peterman and D. Deligiorgis (2020), “FiveWays governments are responding to violence against women and children during COVID-19", UNICEF Connect [online] https://blogs.unicef.org/evidence-foraction/five-ways-governments-are-responding-to-violence-against-women-and-children-during-covid-19/.

Guedes, A. and others (2016), Bridging the gaps: a global review of intersections of violence against women and violence against children, Global Health Action [online] http://dx.doi.org/10.3402/gha.v9.31516.

ILO (International Labour Organization) (2020), Panorama Laboral 2019: América Latina y el Caribe, Lima. (1999), "Worst Forms of Child Labour Convention (No. 182)", Geneva, 17 June.

ILO/ECLAC (International Labour Organization/Economic Commission for Latin America and the Caribbean) (2020), "The COVID-19 pandemic could increase child labour in Latin America and the Caribbean", Technical Note, No. 1, Santiago.

Inter-Agency Working Group on Violence against Children (2020), Agenda for Action [online] https://www. ohchr.org/Documents/Events/COVID-19/Agenda_for_Action_IAWG-VAC.pdf.

INTERPOL (2020), "COVID-19 cyberthreats" [online] https://www.interpol.int/Crimes/Cybercrime/COVID19-cyberthreats.

ITU (InternationalTelecommunication Union) (2020), Guidelines for Parents, Guardians and Educators on Child Online Protection [online] https://www.itu.int/dms_pub/itu-s/opb/gen/S-GEN-COP.EDUC-2016-PDF-E.pdf.

Nguyen, K. and others (2018), "Sampling design and methodology of the Violence Against Children and Youth Surveys" [online] https://www.togetherforgirls.org/wp-content/uploads/Dise\%C3\%B1odel-muestreo-y-metodolog\% C3\%ADa-de-las-Encuestas-sobre-la-Violencia-contra-Ni\%C3\%B1 osNi\%C3\%B1as-y-J\%C3\%B3venes.pdf.

OECD (Organization for Economic Cooperation and Development) (2020), "COVID-19 in Latin America and the Caribbean: An overview of government responses to the crisis" [online] https://read.oecd-ilibrary. org/view/?ref=129_129907-eae84sciov\&title=COVID-19-in-Latin-Amercia-and-the-Caribbean_Anoverview-of-government-responses-to-the-crisis.

Peterman, A., A. Bhatia and A. Guedes (2020), Remote data collection on violence against women during COVID-19: A conversation with experts on ethics, measurement \& research priorities [online] https:// www.unicef-irc.org/article/1997-remote-data-collection-on-violence-against-women-during-covid-19-aconversation-with.html.

Peterman, A., M. O'Donnell and T. Palermo (2020), "COVID-19 and violence against women and children what have we learned so far?", CGD Note, Center for Global Development, June.

Peterman, A. and others (2020a), "Pandemics and violence against women and children", CGD Working Paper, 528, April.

(2020b), "Violence unveiled: COVID-19 is shining a spotlight on domestic abuse", unpublished.

Pinheiro, S. (2006), World report on violence against children, New York, United Nations.

Santos, M. (2020), "Multidimensional Poverty in times of COVID-19" [online] https://www.latinamerica. undp.org/content/rblac/es/home/blog/2020/pobreza-multidimensional-en-tiempos-del-covid-19.html.

Seddighi, H. and others (2019), "Child abuse in natural disasters and conflicts: a systematic review", Trauma, Violence \& Abuse, March.

Together for Girls (2020), Violence against Children Surveys [online] https://www.togetherforgirls.org/ violence-children-surveys/.

Tres, J. and M. Chatruc (2020), “Migrantes y COVID-19: ¿Qué están haciendo los países de América Latina con más migrantes para apoyarlos durante la pandemia?", La maleta abierta, Inter-American Development Bank (IDB) [online] https://blogs.iadb.org/migracion/es/migrantes-y-covid-19-que-estanhaciendo-los-paises-de-america-latina-con-mas-migrantes-para-apoyarlos-durante-la-pandemia/.

Trucco, D. and A. Palma (2020), "Infancia y adolescencia en la era digital: un informe comparativo de los estudios de Kids Online del Brasil, Chile, Costa Rica y el Uruguay," Project Documents (LC/TS.2020/18/ REV.1), Santiago, Economic Commission for Latin America and the Caribbean (ECLAC).

UN-Habitat (United Nations Habitat Assembly of the United Nations Human Settlements Programme) (2015), Déficit habitacional en América Latina y el Caribe: una herramienta para el diagnóstico y el desarrollo de políticas efectivas en vivienda y hábitat, Nairobi.

UNESCO (United Nations Educational, Scientific and Cultural Organization) (2020), "Education: from disruption to recovery" [online] https://en.unesco.org/covid19/educationresponse.

UNICEF (United Nations Children's Fund) (n/da), "Cyberbullying: What is it and how to stop it" [online] https://www.unicef.org/es/end-violence/ciberacoso-que-es-y-como-detenerlo.

_(n/db), "Sexual violence against children" https://www.unicef.org/protection/57929_58006.html.

_(2020a), "Promoción del cuidado cariñoso y sensible de los niños y niñas y el autocuidado a cuidadores para prevenir la violencia en la primera infancia en tiempos de COVID-19. Marco conceptual y metodológico", forthcoming. 
_ (2020b), Policy Brief: The Impact of COVID-19 on children, New York, April.

(2020c), A Generation to Protect: Monitoring violence, exploitation and abuse of children within the SDG Framework, New York.

__(2020d), "Gender-based violence in emergencies" [online] https://www.unicef.org/protection/genderbased-violence-in-emergencies.

_ (2020e), For Every Child, Reimagine UNICEF Annual Report, New York.

(2019), Family-friendly policies: Redesigning the workplace of the future [online] https://www.unicef.org/ documents/family-friendly-policies-redesigning-workplace-future.

(2018), Violencia en la primera infancia: una revisión teórica para América Latina y el Caribe. Resumen de políticas y recomendaciones de Programa, Panama City.

_ (2015), "Violence against Children" [online] https://data.unicef.org/topic/child-protection/violence/.

_ (2006), Behind Closed Doors: The Impact of Domestic Violence on Children, New York.

UNICEF (United Nations Children's Fund)/Save the Children (2020), "Children in monetary poor households and COVID-19:Technical Note" [online] https://www.unicef.org/media/69656/file/TechnicalNote-Childrenliving-in-monetary-poor-households-and-COVID-19.pdf.pdf.

United Nations (2020a), "Secretary-General's Appeal for Global Ceasefire" [online] https://www.un.org/sg/ en/content/sg/statement/2020-03-23/secretary-generals-appeal-for-global-ceasefire.

(2020b), Policy Brief: The Impact of COVID-19 on Latin America and the Caribbean, July.

(2013), The Six Grave Violations against Children during Armed Conflict: The Legal Foundation, Office of the Special Representative of the Secretary-General for Children and Armed Conflict (ORESG-NCA).

(2006), "General Comment No. 8 (2006) The right of the child to protection from corporal punishment and other cruel or degrading forms of punishment (arts. 19; 28, para. 2; and 37, inter alia)" (CRC/C/GC/8), Committee on the Rights of the Child.

UNODC (United Nations Office on Drugs and Crime) (2020), "Impact of the COVID-19 Pandemic on trafficking in persons", Thematic Brief, Vienna.

Vaca Trigo, I. (2019), "Oportunidades y desafíos para la autonomía de las mujeres en el futuro escenario del trabajo", Gender Affairs series, No. 54 (LC/TS.2019/3), Santiago, Economic Commission for Latin America and the Caribbean (ECLAC).

WHO (World Health Organization) (2020a), Global Status Report on Preventing Violence Against Children 2020, Geneva.

_ (2020b), "Coronavirus disease (COVID-19) pandemic" [online] https://www.who.int/emergencies/ diseases/novel-coronavirus-2019.

(2018), Nurturing care for early childhood development, Geneva.

World Bank (2020), "Global economic prospects, June 2020", A World Bank Group Flagship Report, Washington, D.C.

This report was prepared by the Economic Commission for Latin America and the Caribbean (ECLAC) and the Regional Office for Latin America and the Caribbean of the United Nations Children's Fund (UNICEF). The Executive Secretary of ECLAC, Alicia Bárcena, the Acting Regional Director of UNICEF for Latin America and the Caribbean, Bernt Aasen, and the Special Representative of the Secretary-General on Violence against Children, Najat Maalla M'jid, oversaw the preparation of this report.

The report was written by the Social Development Division of ECLAC and the Public Partnerships and Protection Units of the Regional Office for Latin America and the Caribbean of the United Nations Children's Fund (UNICEF), with the support of the consultant, Fabio González.

Copyright (C) United Nations, 2020

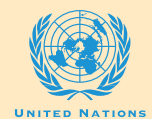

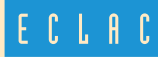

Economic Commission for Latin America and the Caribbean (ECLAC) www.eclac.org of the United Nations Children's Fund (UNICEF) https://www.unicef.org/lac/en

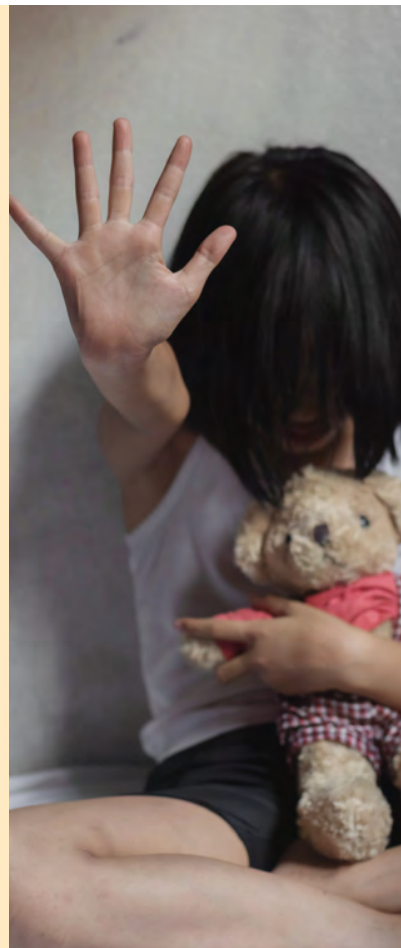

